\title{
TWENTY FIRST CENTURY SKILLS THROUGH PROBLEM BASED LEARNING: AN ESP PERSPECTIVE
}

\author{
Victoria Tuzlukova, Vindhya Singh \\ Sultan Qaboos University, Oman \\ Phone: + 968 24141640, E-Mail: victoria@squ.edu.om
}

\begin{abstract}
Aimed at exploring such category embodied in pedagogical content knowledge (Grossman, 1990) as knowledge of English for Specific Purposes (ESP) instructional strategies useful for teaching content, this paper uses English for Business course offered at Sultan Qaboos University in the Sultanate of Oman as its context. While placing given attention to the analysis of how application of content and the process of problem-based learning can help Omani ESP students develop $21^{\text {st }}$ century skills, it provides a detailed information about the integration of problem solving skills development throughout the course curriculum and teaching materials, as well as the processes of students' learning about how to think and solve problems through facilitated problem solving and selfdirected learning. Recommendations for the effective integration of problem-based learning in ESP programs are provided.
\end{abstract}

Key words: ESP, problem based learning, $21^{\text {st }}$ century skills, language teaching and learning, Sultan Qaboos University, Oman

\section{INTRODUCTION}

Techno sphere's growth - the development and spread of information and communication technologies, interdisciplinary collaborations, pressing need of modern workplaces for new skills and competencies have made teaching and learning a global experience. The rapidly changing world of work requires a unique combination of "soft skills" (personal and interpersonal) - and "hard skills" (technical, problem-solving) that now distinguish $21^{\text {st }}$ century corporate work culture. According to Wagner (2008):

"Work is no longer defined by your specialty; it is defined by the task or problem you and your team are trying to solve or the end goal you want to accomplish. Teams have to figure out the best way to get there - the solution is not prescribed. And so the biggest challenge for our front-line employees is having the critical-thinking and problem-solving skills they need to be effective in their teams - because nobody is there telling exactly what to do. They have to figure it out" (p.15).

Employers are keen to have career ready students who are equipped with the $21^{\text {st }}$ century skills (Binkley, Erstad, Herman, Raizen, Ripley \& Rumble, 2010), especially the four Cs of communication, collaboration, critical thinking and creativity. Masduqi (2011) emphasizes significant roles that skills of critical thinking play both in the academic achievements of the students and "in their dynamic life of workforce after graduation" (p.186). Hirose (1992) gives special importance to promoting critical thinking in 
curricula and teaching practices for students to be prepared to function effectively in today's labor market. As well as that, a typical graduate is now expected to go beyond the textbook and the prescribed syllabus and show evidence of both theoretical knowledge and its practical applications.

According to Silva (2009), now there is much more emphasis on what people can do with the knowledge they can access, in contrast with the fact that the possession of detailed facts and figures was once a passport to a professional job. However, many entry level roles do not get the right candidate due to the widening skill gap that exists between the learning outcomes at the university level and the expectations at the employment scenario. To illustrate, according to "The Middle East Skills Report" of a joint study conducted by Bayt.com, the Middle East's number one job site, and YouGov, a research and consulting agency, 52 per cent of respondents in the Sultanate of Oman believe that there is a skills gap in the market. As reported in Muscat Daily (July 25, 2017), an Omani newspaper, job seekers believe that the educational system does not train students on skills which are relevant in today's marketplace. From their perspective, there is also a "lack of awareness" of what skills are in high demand. The support of this perspective comes also from the employers. Such response from both job seekers and employers has necessitated a closer look at the present general directions in which teaching in the country is developing to nurture our students, and equip them with "lifelong learning and thinking skills necessary to acquire and process information in an ever changing world" (Cotton, 1991 cited in Karakoc, 2016, p.82). For example, while examining $21^{\text {st }}$ century higher education trends in Oman, Baporikar (2013) contends that "in order to participate in the knowledge economy a different set of human skills are required, and what truly matters is higher qualifications, intellectual independence, and flexibility" (p.141). Hence, research aimed at examining how academic programs can provide skills employers require and identifying how to better attach the term $21^{\text {st }}$ century skills to any subject for it to fit the purpose of higher education (Neisler, Clayton, Al-Barwani, Al Kharusi, \& Al-Sulaimani, 2016; Tuzlukova, Al-Busaidi $\&$ Burns, 2017, etc.) is continuing to be important in Oman. One specific aspect involved in such examination is the pedagogical issue, more specifically, knowledge about the instructional strategies useful for teaching content (Grossman, 1990), enhancing students' skills and closing the skills gap.

This paper uses English for Business course offered at Sultan Qaboos University in the Sultanate of Oman as the context for exploring such category embodied in pedagogical content knowledge (Grossman, 1990) as knowledge of ESP teacher about the instructional strategies useful for teaching content. In particular, it focuses on how application of content and the process of problem-based learning can help Omani ESP students develop $21^{\text {st }}$ century skills. It starts with an overview of problem-based learning as one of the popular instructional approaches aimed at helping students further improve their skills and abilities, including the ability to solve problems beyond the usual pattern. Then, it provides detailed information about how the development of problem solving skills is integrated throughout the course curriculum and teaching materials, and how students learn to think and solve problems through facilitated problem solving and selfdirected learning. The focused attention here is placed on the analysis of the application of content and the process of learning. At the end, recommendations for the effective integration of problem-based learning in ESP programs are given. 


\section{TWENTY FIRST CENTURY SKILLS AND PROBLEM-BASED LEARNING: RELEVANCE IN ESP CONTENT AND CONTEXT}

The term $21^{\text {st }}$ century skills refers to a broad set of knowledge, skills, work habits, and character traits which are viewed as crucially important to be successful in today's world, particularly in higher education programs and courses, and contemporary careers and workplaces. This view is shared by both educators and employers. Generally speaking, these skills can be applied in all academic subject areas, and in all educational, career, and civic settings throughout a student's life (The glossary of education reform, n.d., n.p.). According to the glossary of education reform, "the $21^{\text {st }}$ century skills concept is motivated by the belief that teaching students the most relevant, useful, in-demand, and universally applicable skills should be prioritized in today's schools, and by the related belief that many schools may not sufficiently prioritize such skills or effectively teaching them to students. The basic idea is that students, who will come of age in this century need to be taught different skills than those learned by students in the previous century, and that the skills they learn should reflect the specific demands that will be placed upon them in a complex, competitive, knowledge-based, information-age, technology-driven economy and society" (The glossary of education reform, n.d., n.p.).

Research reveals that $21^{\text {st }}$ century skills are relevant to all areas of academic study, may be taught in a wide variety of in-school and outside-of-school settings while utilizing educational approaches that inherently encourage or facilitate the acquisition of crossdisciplinary skills. The concept of English for Specific Purposes refers to "preparing learners to use English within academic, professional, or workplace environments" (Basturkmen, 2006, p.17). Basturkmen (2006) explains that the key feature of ESP courses is "that the syllabus is based on an analysis of the needs of students" (p.17). Popovska and Piršl (2013) contend that, "the ESP as a tertiary education subject can help the development as well as further support of a knowledge society value system by using strategies and methods that enhance both personal and professional growth of the learners" (p.37). They further explain that "ESP courses, as part of the tertiary curricula, can be designed to stimulate, develop and enhance competences and aptitudes which are imperative for recognition and acceptance of high value systems which in turn are expected to be characteristic for highly developed societies like the knowledge society towards which the open minded world has been actually heading today" (p.43).

ESP has always been at the forefront of studies that are connected with finding more efficient ways and methods of English language teaching and learning (Tarnopolsky \& Vysselko, 2014), and English for business as "English for the purposes of effective communication in business in a variety of specific business contexts (Medvedeva 2003 cited in Ilić, 2014, p.541), is no exception. According to Anissimova (2003 cited in Ilić, 2014), the overall objective of a Business English course is to improve performance. Medvedeva (2003 cited in Ilić, 2014) argues, that Business English is a "thicker layer cake" and identifies its numerous layers which include, for example, such skills as problem-solving, communication, decision making skills in addition to cultural awareness, knowledge of business and languages. Our focus is on how application of content and the process of problem-based learning can help Omani students develop such skills through consistent practice in the ESP classroom to address their business communication needs and practices. 


\section{ANALYZING THE CONTENT AND PROCESS OF LEARNING}

Similar to other global and regional educational contexts, better preparedness for the future is an urgent need in the Sultanate of Oman. The country's higher education institutions are compelled to address the economic diversification process by equipping the Omani youth with skills and competencies to develop self-reliance, metacognitive abilities, self-directed study behavior and the confidence to tackle problems in innovative ways. Consequently, there have been adaptations and changes in delivery strategies, teaching methods and instructional approaches to support students' learning and their skills' development in response to the changing realities and imperatives of today "driven by profound social, political, economic and technological changes... continual increases in computing power, the spread of e-commerce, the rapid diversification of the workforce, the globalization of the economy, and the relentless ratcheting upward of the pace of business - all at an ever-accelerating rate of change" (Goldman, Boyatzis \& McKee, 2002, p.246).

Problem-based learning is one popular instructional approach in Sultan Qaboos University in Oman aimed at helping students further improve their skills, nurture their metacognitive abilities and bring them towards a deeper and clearer understanding about the world around them. Based on four modern insights into learning, namely constructive, self-directed, collaborative and contextual, problem based learning has the potential to prepare students more effectively for future learning (Dolmans, De Grave, Wolfhagen \& van der Vleuten, 2005). As well as that, focusing on three characteristics: problems as a stimulus for learning; teacher as a facilitator and group work as a strategy for effective interaction (Dolmans et al., 2005), this method of instruction challenges students to identify and solve problems and acquire knowledge by working together in groups to seek solutions to real world ill-structured problems.

The content of the problem based learning task relies on the constructive learning principle, where students facilitate the construction and modification of meaning based on their background knowledge and initiative to pursue information. Learning is therefore seen as a process for creating meaning and in developing multiple interpretations through deeper interaction in the group. By anchoring learning in meaningful contexts (Ertmer \& Newby, 1993), the problem based learning task enables students to view the problem from a different point of view, and learn how to transfer knowledge in new ways and to develop life-long learning skills.

Studies on problem-based learning (Norman \& Schmidt, 1992) show that utilizing prior knowledge encourages transfer of skills, increased retention and enhanced use of knowledge. By learning in context, there is sufficient stimulus for the transfer of knowledge. This in turn tends to encourage both self-directed and life-long learning skills. Scaffolding prior knowledge with new interpretations of updated information enable students to look for solutions which are both innovative and creative.

In the English for Business courses offered at the Centre for Preparatory Studies of Sultan Qaboos University, the development of problem solving skills is integrated throughout the curriculum. For example, the general objective of English for Business III (LANC 2070) course is to further develop students' skills for academic studies in the College of Economics and Political Science. The course consists of two components: a business case studies' component, and a problem based learning component that emphasizes the use of task-based problems from the disciplines related to business studies 
to engage students in active and multidisciplinary learning. The objectives of problem learning component match course objectives, ESP program outcomes and Sultan Qaboos University graduate attributes. For example, Sultan Qaboos University graduate attribute (A) stipulates that the university graduates should be able to apply the knowledge and skills relevant to the specialization, communicate effectively and use information and communication technologies, critically analyze complex information and present it in a simple, clear manner. Problem-based learning component objectives involve constructing logically written arguments supported by source material, synthesizing and analyzing qualitative and quantitative data, synthesizing information from a variety of sources. Through problem-based learning, students learn how to solve problems that are ill structured and open-ended, and to apply knowledge in an authentic way.

Problem-based learning is viewed as a fundamental part of learning English for Business. This course component exposes Omani students to real-world challenges, higher order thinking skills, interdisciplinary learning, independent learning, information mining skills, team work and communication. As for teaching materials in the problem based learning component, English for Business III (an in-house) textbook, a variety of supplementary materials, and online materials and tasks on Moodle platform (discussion forums, videos, etc.) are used. The core textbook and teaching materials feature functional business English with focused systematic practice of four skills, clear presentation of the vocabulary and in-depth ESP grammar syllabus. Also, they promote higher forms of thinking on a variety of cognitive levels (Bloom, Engelhart, Furst, Hill \& Krathwohl, 1956), and integrate vocabulary related to effective problem solving, e. g. choose, define, analyze, compare, apply, combine, contrast, classify, conclude, identify, order, deduce, judge, justify, solve, etc.

In problem based learning, students work together, discuss, compare, review and debate what they have learnt. The main principles of the problem based learning in the context of English for Business III (LANC 2070) course include (a) collaborative learning that involves groups of students working together to solve a problem, complete a task, or create a product; (b) constructive learning that suggests constructing knowledge and meaning from experiences; (c) contextual learning that involves making learning meaningful to students by connecting it to the real world. It draws upon students' diverse skills, interests, experiences, and cultures and integrates these into what and how students learn and how they are assessed; (d) self-directed learning refers to a process in which individuals take the initiative, with or without the help of others, in diagnosing their learning needs, formulating learning goals, identifying human and material resources for learning, choosing and implementing appropriate learning goals and objectives.

During the problem based learning classes, students speak, read and write to explore, extend, clarify, and reflect on their thoughts, ideas, feelings, and experiences. Since the problem assigned for them to solve is open-ended and does not require a prescribed approach to problem solving, students are expected to demonstrate new ways of thinking. They are also expected (a) to engage in collaborative decision-making and team-building; (b) to select, read, and view with understanding a range of literature, information, media, and visual texts; (c) to use writing and other forms of representation to explore, clarify, and reflect on the thoughts, feelings, experience; (d) to interact and create texts collaboratively and independently, using a variety of forms for a range of situations; (e) to communicate information and ideas effectively and clearly, and respond personally and critically. 
In Business English III course, students learn to think and solve problems through facilitated context-rich (Nilson, 2010) problem solving tasks. Similar to previous English for Business LANC courses, in LANC 2070 course the content of the problem based learning component is introduced to the students in the context of complex real-world problems. These are researched through an open-ended real life scenario. However, the problem scenario in LANC 2070 is different from the previous courses. It pertains to setting up a charity in a country outside Oman with a group of peers who share a passion for a similar cause. Also, students are asked to design a website of their charity and write an academic report.

Students are engaged in self-directed learning. The instruction is aimed at developing in students the ability to solve problems beyond the usual pattern - that is, the ability to transfer problem solving skills to situations students have not tried/attempted before. The focused attention is also placed on the application of content and the process of learning. Consequently, as suggested by Elder and Paul (2003) "through consistent practice, students will eventually develop their abilities to construct ideas into their thinking, to accurately assess what they are reading, and to think within the viewpoint of authors (even those with whom they disagree)" (p.36). The students collaborate as a group and communicate their ideas which should ideally help them to critically engage in problem solving. Thus, as rightly emphasized by Nilson (2010) "because students talk out their different ideas and evaluate alternative approaches, they acquire individual problemsolving skills in the process" (p.197).

In-depth inquiry into the background of the product and a holistic approach to finding solutions enable reflection and revision of ideas. In the English for Business III course, for instance, students work in the optimal size groups of three or four, to identify an illstructured real-world problem in a country of their choice. First, they brainstorm a problem in the real world, which is humanitarian in nature and determine what they know about the problem (background knowledge), what they need to learn more about (topics to research), and where they need to look to find data (databases, interviews, etc.). The solution will be to offer support through an international charity which will be set up in the country.

It is important to ensure that the problem based learning task has an ill structured problem, which is situated in a relaxed and supportive learning environment, and the right mix of elaboration, cohesion and motivation by the teacher to facilitate the learning curve in problem based learning. The problem needs to be authentic, adapted to the students' level of prior knowledge, enable students to engage in collaborative thinking in small groups and supported by flexible scaffolding from the teacher. Regular feedback given on a regular basis also helps in easing out problems with group dynamics (Dolmans et al., 2001) and self-directed learning.

In classes that utilize problem based learning instructional approach, students develop the ability to solve problems independently and develop the ability to transfer problem solving skills to new situations. The application of content to the process of learning enables them to negotiate meaning in unfamiliar contexts. By consistent practice, "students will eventually develop their abilities to construct ideas into their thinking, to accurately assess what they are reading, and to think within the viewpoint of authors" (Elder and Paul (2003, p.36). Students are given space to share different ideas and evaluate ways of seeking solutions, thereby leading to the development of problem solving skills (Nilson, 2010, p.197). 
Students engage in a research based inquiry into the background of the idea and adopt a holistic approach to finding multiple possible solutions to the problem. In the English for Business III course, for instance, students work in groups of three or four to identify an ill-structured real-world problem in a country of their choice. The group members need to develop solutions that will be offered through an international charity which will be set up in the selected country. It is an academic opportunity of the students to discuss, analyze and evaluate real-world problems. This provides "interesting, meaningful and challenging contexts for students" to develop their skills (Nilson, 2010, p.198). Students are also engaged in cognitive collaboration and develop problem-solving expertise (Heller, Keith \& Anderson, 1992), group dynamics and team work as they critically analyze the specific situation and suggest creative solutions through the services offered by the international charity. Creative expression of ideas is also given a chance through logo and website creation. The PEST and SWOT analyses give a strong rationale to the task and help develop independent research skills, self-reliance and group dynamics among students. Problem based learning, therefore, can lead students to skills development which goes beyond the confines of a teacher centered classroom and moves into student centric, self-directed ways of problem solving and innovative thinking. More importantly, students play an active role in meaning creation by identifying the problem, conceptualizing the issues behind the problem, planning the ways to approach the task, setting goals to complete the task through developing vision and mission statements and selecting ways to monitor their own progress into task completion through timeline development and finally to identify limitations and recommendations for the future.

Collaboration, one of $21^{\text {st }}$ century skills, in English for Business III course is focused on through the problem based learning task to serve a dual purpose. In addition to encouraging students to divide the work in a fair manner among the group members, it also encourages mutual respect and interaction, willingness to listen and adapt thinking to a commonly agreed goal and develop a shared understanding of issues related to an identified problem through open interaction. Co-construction of meaning and developing multiple solution options is encouraged by such situated learning, where students learn to give mutual support and constructive criticism and tuning in cognitively and socially (Billet, 1996). On the one hand, "real-world problems furnish more interesting, meaningful and challenging contexts for students to apply and hone their skills (Nilson, 2010, p.198). On the other hand, students are engaged in cognitive collaboration and develop problem-solving expertise (Heller et al., 1992), group dynamics and team work as they critically analyze the specific situation and suggest creative solutions through the services offered by the international charity. For example, in small groups, students are asked to work collaboratively on the products (presentation and written report) that will present their findings and team work, and use mobile and computer tools and services (e.g. WhatsApp, Google groups, etc.) for their out-of-class digital collaboration.

In the problem-based learning component classes of the English for Business III course, the students' voices find expression as they articulate through PEST analysis and SWOT analysis the rationale for their solutions. Here, digital technology, online services, platforms and tools have thoroughly amended the underlying paradigms of problembased learning component in terms of supporting students' virtual learning, selfpresentation, interactions, and self-reflections. For example, students create their own websites using different online tools and services, e.g., Weebly website builder 
(www.weebly com) or Wix free website builder (www.wix.com/) to announce their inspirations, intentions and plans, begin fundraising and seek contacts for donations.

According to Woods, Hrymak, Marshall, Wood, Crowe, Hoffman, Wright, Taylor, Woodhouse \& Bouchard (1997), a problem-solver is an individual who exhibits a wide range of attributes, including the ability to draw on the pertinent subject knowledge and objectively and critically assess the quality, accuracy, and pertinence of that knowledge. In English for Business course, students are involved in writing activities on Moodle learning platform. This dynamic and flexible platform provides students with a personalized learning environment. For example, students communicate with the teacher and each other, get involved in various types of activities, tasks and interaction that are consequences of their individual choices and needs. These include, for example, selfstudy activities, use of discussion forum tools. Students also record their thoughts and post their reflections on Moodle discussion forum. The reflections are guided by the teacher designed questions about students' perceptions of the content and process of problem-based learning. To illustrate this, one of the examples of tasks on discussion forum includes the following questions: (a) What problem are you planning to address? Why addressing this problem is essential to you? How can this experience be turned into expertise that will help you address or solve other kinds or similar types of problems or situations? (b) What have you learnt about teamwork from the PBL project so far? (c) What have you learnt by doing this PBL projects? What challenges did you face while working on your charity? What higher order thinking skills did this project help you to learn and apply?

In Harter's view (1999), self-perceptions can be described as the impressions a person has relating to their own abilities in different domains or contexts. There is a broad body of research evidence that suggests that self-reports of learning, or perceived learning, can be a valid measure of learning (Pace, 1990; Rovai \& Barnum, 2003). It also provides evidence that students' perceptions may be more important than reality, as decisions about learning are often based on perceptions (Rovai \& Barnum, 2003).

The initial examination of students' self-reflections shows students' positive response to their participation in problem-based learning classes. According to them, these classes contributed to developing their skills of working in teams and sharing ideas, managing time and paraphrasing, critical thinking and problem-solving. Students reported that they have become more responsible, and learnt about the importance of being respectful while working in teams. As one student wrote in her reflections: "... this course component has helped us to deal with different minds and break the barriers". Another student explained that problem-based learning had given them "more knowledge on how to working as a group or a team". According to this student: "group members have different backgrounds, skills and experiences so we learned how to coordinate and divide the assignments among group members". In their self-reflections, students also wrote about their enhanced their communicative competence, team working skills and levels of confidence in using business specific vocabulary. For example, one of the students wrote: "In this project, I have learnt many things, such as communication, group work and how we can do charity. The first thing is communication. Communication is requested in doing the project for that I have improved my communication skills with others. The second thing is group work. Group work is about people who are more than two work together for specific goal. Therefore, I concluded that group work is better than individual work. This will help me to do project with group in future. The last thing is how we can do charity. 
For example, in my real life, before I didn't know how the people do charity but now I know that by helping from my teacher and group mates". Her friend was of a similar view and reported that she appreciated learning about how to work with a group. Reflecting on her learning in a problem-based learning class, she also wrote: "In addition, I learnt how to get information from the websites. This skill helped me to come up with new ideas and explain them to others". Students also acknowledged the focus of problembased learning classes on logical thinking and applying higher order thinking skills. As an illustration, one of the students explained that the problem-based learning component of the English for Business course helped her identify her skills and improved her skills of analysis and evaluation. Another student contended: "Problem-based learning promotes lifelong learning and helps students develop their skills. For example, it has helped us to plan our work well, develop our critical thinking, creativity and strong communication skills both for interpersonal and presentation needs".

\section{CONCLUSION}

Our initial investigation of English for Business III course offered at Sultan Qaboos University in the Sultanate of Oman as the context for exploring the instructional approach of problem-based learning in ESP classes found that it is insufficient to teach our students just content and language knowledge and just facts, figures and ideas. Students need to be taught how to manipulate and use them in real-life contexts and settings. They also need adaptable and transferrable skills they can apply in all areas of their academic and professional life. As a result, ESP classes need to adapt and develop new ways of teaching and learning that reflect a changing world. The purpose of language teaching in ESP classes should not be limited to the enhancement of linguistic and content literacies, and language knowledge. It should be organized and structured in a way to get students prepared for successful future at the university and at work, and equip them with $21^{\text {st }}$ century skills, regarded as the most important by university professors and employers. Only teaching students to perform well in language course or on a test is no longer sufficient. Given the widespread availability of information today, students no longer need educators to lecture to them because information is readily available - and often in more engaging formats that a typical lecture. For this reason, educators should use in-class time to teach students how to find, interpret, and use information, rather than using most or all of the time to present information. In ESP classroom, problem-based learning projects and tasks are, to a large extent, a step in the right direction to equip students with the skills needed in the future workplaces in addition to developing confidence to pursue self-employment as a career option.

\section{REFERENCES}

Baporikar, N. (2013). 21st century higher education trends in Sultanate of Oman. In P. O. de Pablos \& R. D. Tennyson (Eds). Strategic role of tertiary education and technologies for sustainable competitive advantage (pp.140-155). IGI Global, Hershey, PA. Retrieved May 1, 2017 from http://www.academia.edu/34350650 /21st_Century_Higher_Education_Trends_in_Sultanate_of_Oman. 
Basturkmen, H. (2006). Ideas and options in English for specific purposes. Mahwah: Lawrence Erlbaum Associates.

Billet, S. (1996). Situated learning: Bridging socio-cultural and cognitive theorizing. Learning and Instruction, 6(3), 263-280.

Binkley, M., Erstad, O., Herman, J., Raizen, S., Ripley, M. \& Rumble, M. (2010) Defining 21st Century skills. Draft white paper. Part of a report to the Learning and Technology World Forum 2010, London.

Bloom, B. S., Engelhart, M. D., Furst, E. J., Hill, W. H., Krathwohl, D. R. (1956). Taxonomy of educational objectives: The classification of educational goals. Handbook I: Cognitive domain. New York: David McKay Company.

Dolmans, D.H., De Grave W, Wolfhagen I.H, \& van der Vleuten C.P. (2005). Problembased learning: future challenges for educational practice and research. Medical Education, 39(7), 732-741.

Elder, L. \& Paul, R. (2003). Critical thinking: Teaching students how to study and learn. Journal of Developmental Education, 27 (2), 36-38.

Ertmer, P.A., \& Newby, T.J. (1993). Behaviorism, cognitivism, constructivism: Comparing critical features from an instructional design perspective. Performance Improvement Quarterly, 6(4), 50-72.

Goldman, D., Boyatzis, R. \& McKee, A. (2002). Primal leadership - realizing the power of emotional intelligence, Harvard Business School Press, Boston, Mass.

Grossman, P.L. (1990). The making of a teacher: teacher knowledge \& teacher education. New York: Teachers College Press.

Harter, S. (1999). The construction of the self: A developmental perspective. New York: Guilford Press.

Heller, P., Keith, R., \& Anderson, S. (1992). Teaching problem solving through cooperative grouping. Part 1: Group versus individual problem solving. American Journal of Physics, 60(7), 627-636.

Hirose, S. (1992). Critical thinking in Community Collages. ERIC Digest. Retrieved June 15, 2018 from http://www.ericdigest.org/19922/critical.htm.

Ilić, K. (2014). Attitudinal implications in teaching and learning business English. The Journal of Teaching English for Specific and Academic Purposes, 2(3), 541-547.

Karakoc, M. (2016). The significance of critical thinking ability in terms of education. International Journal of Humanities and Social Science, 6(7), 81-84. Retrieved June 30, 2018 from http://www.ijhssnet.com/journals/Vol_6_No_7_July_2016/10.pdf.

Masduqi, H. (2011). Critical thinking skills and meaning in English language teaching. TEFLIN Journal, 22 (2), 185-200.

Neisler, O., Clayton, D., Al-Barwani, T., Al Kharusi, H., \& Al-Sulaimani, H. (2016). 21st century teacher education: Teaching, learning and assessment of critical thinking skills at Sultan Qaboos University. In Redefining Teacher Education for the Post2015 Era: Global Challenges and Best Practices (pp. 77-95). Nova Science Publishers, Inc.

Nilson, L. (2010). Teaching at its best: A research-based resource for college instructors. 3rd ed. San Francisco, CA: Jossey-Bass.

Norman, G. R., \& Schmidt, H. G. (1992). The psychological basis of problem-based learning: A review of the evidence. Academic Medicine, 67(9),557-565. 
Pace, C.R. (1990). The undergraduates: A report of their activities and progress in college in the 1980's. Los Angeles, CA: Center for the Study of Evaluation, University of California, Los Angeles.

Popovska, S. \& Piršl, D. (2013). The role of ESP in society's value system. The Journal of Teaching English for Specific and Academic purposes, 1(1), 29-43.

Reis, D. (2012). New way to capture student narratives and reflection in Moodle. Retrieved January 15, 2018 from http://blogs.elon.edu/technology/new-way-tocapture-student-narratives-and-reflection-in-moodle/).

Rovai, A.P. \& Barnum, K.T. (2003). On-line course effectiveness: An analysis of student interactions and perceptions of learning. Journal of Distance Education. 18(1), 57-73. Retrieved on 16thSeptember, 2011 from http://topshare.che.nl/download attachment/177224/Artike1\%20over\%20eff\%20van\%20online\%20studeren.pdf.

Silva, E. (2009) Measuring skills for 21st-century learning. Phi Delta Kappa, 90(9), 630634.

Tarnopolsky, O. \& Vysselko, A. (2014). Mini-courses on economic disciplines in an advanced ESP course for university students on economics. The Journal of Teaching English for Specific and Academic Purposes, 2(1), 45-59.

The glossary of education reform. (n.d.). Retrieved April 12, 2018 from https://www. edglossary.org/21st-century-skills/.

Tuzlukova, V., Al-Busaidi, S. \& Burns, S. (2017). Critical thinking in the language classroom: Teacher beliefs and methods. Pertanika, Social Sciences \& Humanities, 25(2), 615-634.

Wagner, T. (2008). The global achievement gap: Why even our best schools don't teach survival skills our children need - and what we can do about it. Basic Books.

Woods D.R., Hrymak, A.N., Marshall, R.R., Wood, P.E., Crowe, C.M., Hoffman, T.W., Wright, J.D., Taylor, P.A., Woodhouse, K.A. \& Bouchard, C.G.K. (1997). Developing problem solving skills: The McMaster problem solving program. ASEE Journal of Engineering Education. 86(2), 75-91. 